\title{
The Anticancer Effects of Hexane Extract of Rainbow Trout (Oncorhynchus mykiss) Muscle Enriched with Vegetable Oil Brasica sp.
}

\author{
Poroshad Montazeri Shahtoori ${ }^{1}$, Mozhgan Emtyazjoo ${ }^{1,}$, , Shahin Bonakdar ${ }^{2}$, Mohammad Rabani ${ }^{1}$ \\ ${ }^{1}$ Faculty of marine science and technology, Islamic Azad University North Tehran Branch, Tehran, Iran \\ ${ }^{2}$ National cell Bank Department, Faculty of Pasteur Institute of Iran, Tehran, Iran
}

Email address:

moz_emtyazjoo@yahoo.com (M. Emtyazjoo)

\section{To cite this article:}

Poroshad Montazeri Shahtoori, Mozhgan Emtyazjoo, Shahin Bonakdar, Mohammad Rabani. The Anticancer Effects of Hexane Extract of Rainbow Trout (Oncorhynchus mykiss) Muscle Enriched with Vegetable Oil Brasica sp.. Cancer Research Journal.

Vol. 3, No. 4, 2015, pp. 63-67. doi: 10.11648/j.crj.20150304.11

\begin{abstract}
Background: As Canola oil (Brasica sp.) has beneficial compositions of essential fatty acids like saturated fatty acids, mono unsaturated fatty acids (MUFA) and poly unsaturated fatty acids (PUFA), practically it use in many experimental purposes. There are considerable amounts of oleic acid which is mono unsaturated fatty acids in canola oil that caused a good resistance to thermal processes such as deep frying. Rainbow trout is the main fish species farmed in about $85 \%$ of the total rate allocated to producing aquaculture fish in Iran. Rainbow trout has found in food baskets of many people due to its high nutritional value. Methods: in this study the hexane extracts of fish muscle isolated with purity of $250,50,10,5 \mathrm{and} 0.5 \mu \mathrm{g} / \mathrm{ml}$ at regular intervals of 24, 48 and 72 hours to determine the effects of hexane extracts on parameters which are associated with the survival of skin cancer cells A431 by MTT method in vitro comparison. Results: The effect of various concentrations of hexane extracts from fish muscle showed that the extracts of muscle at varying time intervals in hexane extracts administration had different effects on mortality of A431 cancer cells. Increasing of hexane extracts had significantly decreased the carcinogenic cells. The concentrations of hexane extract in $250 \mu \mathrm{g} / \mathrm{ml}$ at 24 hours were killed 50 percent of skin cancer A431 cell lines. The addition of Brasica sp. vegetable oil as a dietary supplement is required to fish diet rations. Conclusion: In the present study the hexane extract inhibit the growth of cancer cells where the extract can be used as an anticancer agent for the operation of this lineage.
\end{abstract}

Keywords: Cancer, Rainbow Trout (Oncorhynchus mykiss), Canola Oil (Brasica sp.), MTT Assay

\section{Introduction}

Today, due to civilization and industrial developments, the tendency of people to change their diet pattern to consumption of processed foods and less physical activity and on the other hand stressful lifestyle etc., people are faced to many health problems and diseases. To prevent such problems all societies need to conduct some strategies to improve community's health level. A proper diet is one of the most important factors to achieve this goal.

Canola oil (Brasica sp.) due to the balance ratio of saturated, mono-unsaturated and poly unsaturated fatty acids is suitable to apply in many food recipes. A significant amount of oleic acid (monounsaturated) in canola oil made it resistant to thermal processes such as deep frying.

The average amounts of $40-45 \%$ Canola oil is in the plant seeds which had a balanced profile of saturated fatty acids (7\%), high levels of mono unsaturated fatty acids (about $61 \%$ ) and a moderate level of poly unsaturated fatty acids (about $32 \%$ ) (Siavash et al., 2005).

Sea foods in comparison with other protein sources have a lot of essential amino acids which is necessary for human body. Also fish muscles are easy to digest because of less connective tissue. In Comparison with other animal sources containing harmful saturated fats, fishes are more preferred to consume.

Cancer is a class of diseases characterized by out-ofcontrol cell growth. There are over 100 different types of cancer, and each is classified by the type of cell that is initially affected. As a single entity, cancer is the biggest cause of mortality worldwide (WHO Global Health Observatory. Available at: 
http://www.who.int/gho/map_gallery/en/) There were an estimated 8.2 million deaths from cancer in 2012. Global cancer incidence over four years increased by $11 \%$ to an estimated 14.1 million cases in (Oity Mayors. Available at: http://www.citymayors.com/statistics/largest-cities-

population-125.html.

Cancer cases worldwide are forecast to rise by $75 \%$ and reach close to 25 million over the next two decades. Good nutrition is especially important if patients have cancer. It helps the body to prevent and treatment in every stage of cancer. Fish is one of the food sources with the special nutrients to prevent cancer. Due to high levels of omega-3 essential fatty acids in fish muscles it increases the strength of body immune system. Also in some studies it is indicated that by the conjunction of omega- 3 fatty acids with cell walls at the beginning step of cell damaging, cyclooxygenase enzyme which is as activator cell damage, get stop (Jafari et al., 2014).

There were no research studies to show the impact of rainbow trout fed by canola oil on cell lineA431 in Iran as well as other regions. Administration of plant oil in diet of rainbow trout which is a carnivorous species is considerable point of this study. The purpose of this study is investigation of the anticancer effect of rainbow trout fed by canola oil on skin cancer cell lineA431.

\section{Materials and Methods}

Fish samples (salmon fish farm), were tested after three times feeding in a day with diet enriched by canola oil for 3 months.

Fishes are selected randomly by using Sachuk equipment. After fishing, muscle, skin and bones, are completely removed, then the fish blended by blender to increase the contact of the muscle surface and the solvent. Due to the carotenoids compounds in our samples those are more sensitive to the light and humidity therefore they should be in the dark and dry environment. The minced muscles were packed, weighed, wrapped in foil and after labeling; they mingle with ice and were kept in refrigerator at $-24^{\circ} \mathrm{C}$. When Samples transferred to the laboratory, they dried by the freeze dryer for preparing to extraction.

Hexane normal solvents were used for extraction. For this purpose, 30 grams of each sample weighed and 100 to 150 $\mathrm{ml}$ of solvent were added to them in the flask then ultrasonic used for 1 hour (in two periods of 30 minute). In the next step, the upper liquids removed by pipette and transferred into centrifuge tube test to centrifuge in 9500 rotations speed per minutes 10 minutes. Again supernatant liquids were separated and by Rotary machine it became concentrate to $5 \mathrm{ml}$ volume under the 27 to $30 \mathrm{C}^{0}$ of temperature and in the last stage of preparation the remaining solution was dried by nitrogen gas. RPMI medium culture was passed through 0.45 micron filter paper on dried hexane extract to reach to $2.5 \mathrm{ml}$ volume.

Human squamous Cell Carcinoma (A431) which was one of the human carcinoma was exposed to hexane extract in
RPMI medium culture for 24, 48 and 72 hours separately. All cells were stained by vital tetrazolium and were counted with Elisa reader. To evaluate the anticancer effects of hexane extract the results were separately analyzed by counting the numbers of carcinoma cells. Vital carcinoma cells were visible in our counting but the dead cells were not visible to count.

Therefore the vital carcinoma cells from the previous stage were washed by buffer PBS, trypsinated and were put in the incubator for 3 minutes. Culture medium RPMI +\% 10 FBS were added to the washed cells and centrifuged for 10 minutes in 1400 the radius of the centrifuge rotor per minutes. Finally by adding a drop of Trypan blue to the mixture, the sample transferred to the Neubauer slide and viewed by inverted microscope. In this study, the effect of hexane extract on cell lines A431 were tested by Di Methyl Thiazolyl Tetrazolium (MTT) method which used in measurement of cell proliferation. Vital conditions of carcinoma cells were calculated by using the following formula (Emtyazjoo et al., 2012):

Percent survival of life: The number of viable cells / total cells $\times 100$

The data was analyzed using the Excel software version 2007. Means and standard deviations were computed for all variables. Analyses of variance (ANOVA), Duncan test, to measure the LC50 of Probit value were used to compare different parameters which were studied by SPSS windows software version 16. (SPSS, Inc., Chicago, IL, USA).

\section{Results and Discussion}

In this study the effects of hexane extract of rainbow trout species on skin cancer cells A431 by MTT method were assessed. The cancer cell survival was compared in different concentrations of hexane extracts $(250,50,10,5$ and 0.5 $\mu \mathrm{g} / \mathrm{ml})$ at different periods of time (72, 48 and 24 hours). Two types of hexane extracts were used in this study, the extract with canola oil and the second one was without canola oil free.

The percentages of survival skin cancer cells exposed to hexane extract were shown in Table 1.

Table 1. The $L C_{50}$ results of A431cell lines exposed to hexane extract of rainbow trout fed by Canola oil at different periods of time.

\begin{tabular}{llll}
\hline LC50 & & & \\
\hline Time (hours) & 24 & 48 & 72 \\
No rapeseed oil & 0 & 0 & 0.006 \\
With rapeseed oil & 0.003 & 0.067 & 0.055 \\
\hline
\end{tabular}

According to table 1 the maximum cancer cells dead on concentration of $5 \mu \mathrm{g} / \mathrm{ml}$ hexane extract for 24 hours and a minimum effect had seen for concentration of $250 \mu \mathrm{g} / \mathrm{ml}$ hexane extract for 48 hours. Biological survival of hexane extract decreased by increasing its concentrations. However the concentration of $10 \mu \mathrm{g} / \mathrm{ml}$ of hexane extracts for 72 hours had a positive effect on cell's dead (Figure 1).

Probit Analysis test to the samples fed with rapeseed oil diet showed that the samples with rapeseed oil in the range of 
24 and 48 hours a zero $\mu \mathrm{g} / \mathrm{ml}$, in 72 hours, $0.006 \mu \mathrm{g} / \mathrm{ml}$ (Within confident 0.001 to 0.019 ) and sample treatment 2 in the interval of 24 hours, $0.003 \mu \mathrm{g} / \mathrm{ml}$ (in the range of reliability 0.001 to 0.006 ), in 48 hours, $0.067 \mu \mathrm{g} / \mathrm{ml}$ (in the range of reliability 0.035 to 0.115 ) and 72 hours $0.055 \mu \mathrm{g} / \mathrm{ml}$ (in the range of 0.029 to 0.096 assurance), had the maximum effect on cancer cells respectively. The three factors of time, concentration and at the same time the fish diet were treated with the highest degree of cell death in the presence of hexane extract at a concentration of $250 \mu \mathrm{g} / \mathrm{ml}, 24$ hours, without food sample was rape.

Hexane extract in different concentrations, the highest death rate is in the concentration of $250 \mu \mathrm{g} / \mathrm{ml}$ (Figure 2) and the lowest mortality rates were seen in the period of 48 hours. The highest mortality rate belonged to 24 hours exposer to hexane extracts (Figure 2). Depending on the type of diet, the highest mortality rate in the sample is free of rapeseed oil. Overall, taking into account three factors, the concentration of hexane extract and food samples, the highest mortality rate in the presence of hexane extract at a concentration of 250 $\mu \mathrm{g} / \mathrm{ml}$ of rapeseed oil has been lacked in the sample. At 72 and 48 hours, the highest mortality rate of the sample concentration of $250 \mu \mathrm{g} / \mathrm{ml}$ of rapeseed oil has been lacked.

The statistical analysis, Tukey test took place for hexane extract. The null hypothesis of equality of variances between the data observed. There was no significant difference in average data for hexane extract at a concentration of 0.5 to 50 $\mu \mathrm{g} / \mathrm{ml},(\mathrm{P}>0.05)$. There was a significant difference for all three period of time, 48 and 24 hours to 72 hours exposure of hexane extract and cancer cells $(\mathrm{P}<0.05)$.

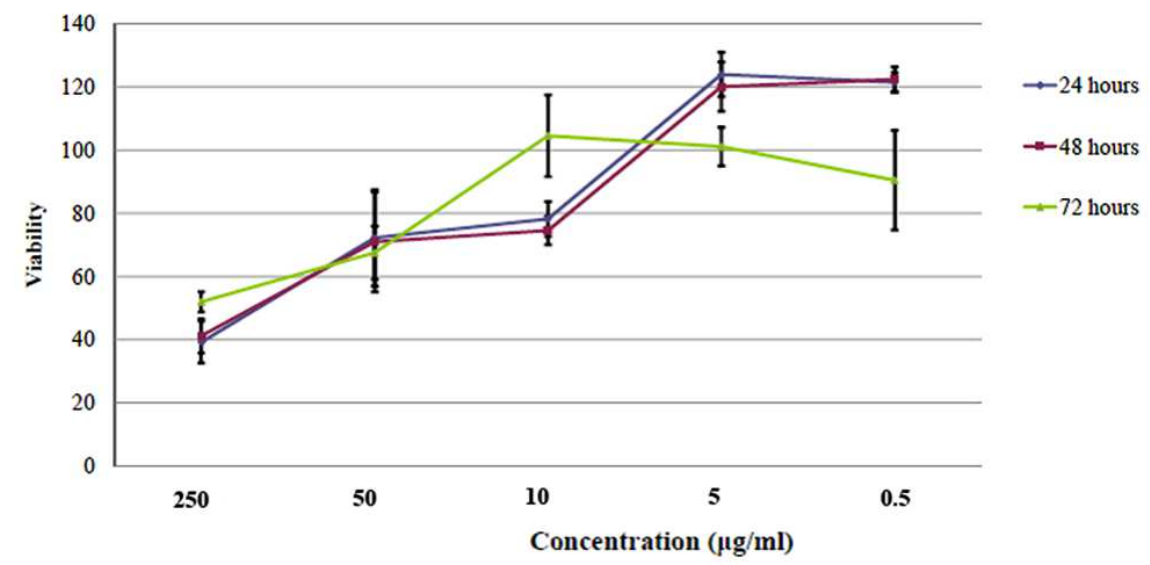

Figure 1. Comparison of biological survival of skin cancer cell lines A431 at hexane extract rainbow trout fed with food rations free of rapeseed oil.

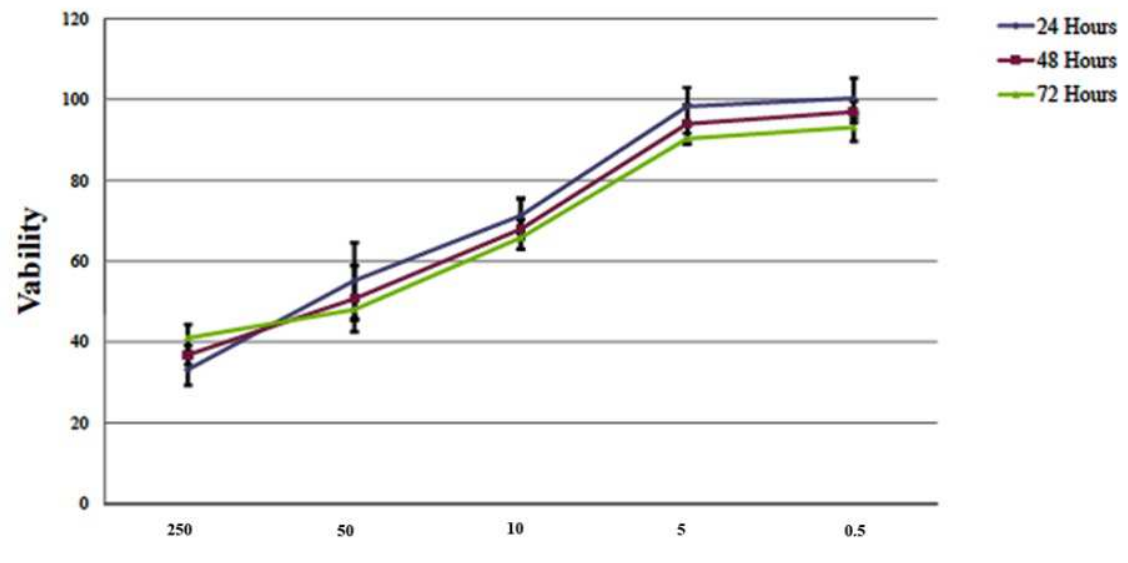

\section{Concentration $(\mu \mathrm{g} / \mathrm{ml})$}

Figure 2. Comparison of biological survival of skin cancer cell lines A431 at hexane extract rainbow trout fed with food rations with rapeseed oil.

\section{Discussion}

Working on anticancer properties of marine animals including fish rainbow trout in the developed world, particularly using cell groups in order to increase the nutritional quality, so the food can be used as food-medicine. In this regard, several studies were conducted in Iran. In this study, rapeseed oil was added to the fish diet and its anticancer effects on skin cancer were examined.

The results of exposure hexane extract to the cell line A431 and its inhibiting effect showed that sample fed by canola; rapeseed oil had more anticancer properties. According to Sadeghi and colleagues studied the effect of the solvent can be related to the purpose and nature of the solvents and the chemical composition of functional groups in the compound (Sadeqi, 2009), as well as differences in 
chemical structure, such as food binders, he said.

An organic solvent and nonpolar solvent hexane and why nonpolar organic dissolving properties as well. Accordingly, with respect to certain of nonpolar compounds in fish muscle's ability to solve it (Yang et al., 2013). In addition, studies have been able to extract the hexane solvent and other compounds such as carotenoids, including beta-carotene and phenols found in the body of the fish (Abo Elmaati et al., 2012). Phycocyanin likely extracted by solvent hexane or methanol solution, has anticancer properties (Zakir et al., 2005) and induced effects on cancer cells and potent antioxidant water is mentioned. A study on the extraction of antioxidants from the treatment plant is 5 solvents hexane and ethyl acetate is used for the extraction of beta-careton and linoleic acid (Mohamed et al., 2012).

Mortality cancer cells can be caused by the presence of beta-carotene in the extract. Beta-carotene is as an antioxidant compound to excreted 1000 free radical (Callem, 1997). Epidemiology documents in 1981 in America by Peto and colleagues found that beta-carotene prevent cancer by the anti-oxidant activity in different parts of the body (Popple \& Goldbohm, 1995; Chidambara et al., 2005; Buiatti, 1997). Beta-carotene to prevent various types of tumors in humans and animals, such as stomach cancer, skin melanoma, head and neck epidermoid and pancreatic secretory gland has been established (Stryker et al., 1990). Because of its antioxidant and anticancer effects of beta-carotene, use in the preparation of food supplements and medication (Tim et al., 2007). Possible mechanisms that could be useful in the treatment of cancer, the role of carotenoids as factors explains the changes in the molecular pathway that carotenoids are signals of cell death (Schwartz et al., 1988).

The results of this study showed that fish fed rapeseed oil, anti-cancer effects than normal fish, it can oleic acid in canola oil and has a double bond in the fatty acids and linoleic acid Omega-3 fatty acids are canola oil and has three double bond is converted in the body to EPA (eicosa pentaenoic acid) and DHA (docosahexaenoic acid) is. According to some nutrition scientists, each of the three fatty acids (oleic, linoleic and linolethic) is necessary and must be received through food. In addition, fatty acids EPA and DHA get sea food is also available directly placed (Parker et al., 2003).

As noted above, because of the advantages of fish proteins, essential unsaturated fatty acids, minerals and vitamins. Omega-3 polyunsaturated fatty acids in fish, especially freshwater and marine fish are also using this advantage of the human body is unable to synthesize polyunsaturated fatty acids omega-3 (PUFA) is not the fatty acids must be supplied through diet. Fish due to high levels of omega-3 essential fatty acids as an important factor in reducing the risk of cancer has been found in several studies (Jafari et al., 2014).

Moreover in canola oil, oleic and linoleic fatty acids detected and according to anti-cancer properties of these compounds can be another death row cells A431 in the presence of these compounds (Parker et al., 2003) .

\section{General Conclusion}

In this experiment, it was found that the most appropriate treatment of rainbow trout, specially the rate of $250 \mu \mathrm{g} / \mathrm{ml}$ hexane extract during 24 hours, killing 50 percent of skin cancer cell line A431.

Add vegetable oil Brasica sp. as a supplement to the rations of fish is recommended that this cause reducing the risk of skin cancer, because the hexane extract resulted in inhibition of growth of cancer cell lineA431 in the present study and the extract can be used as an anticancer for this cell line function.

\section{Acknowledgment}

Thanks official laboratories of Pasteur Institute of Iran, the authorities of the Faculty of Marine Science and Technology, Islamic Azad University, North Tehran.

\section{References}

[1] Abo ElMaati, M.F., Labib, S.M., Al-Gaby, A.M.A. \& Ramadan, M.F., 2012. Antioxidant Properties of Different Extracts from Five Medicinal Plants. Agricultural biochemistry department, Faculty of Agriculture, Zagazig University, Egypt., Vol. 39, No. (4) : 1-13.

[2] Beigmohammadi, Z , Maghsoudlou, Y., Sadeghi Mahoonak, A.R. \& Safafar, H., 2009. Fatty acids Profile, Physicochemical Properties and Mineral Contents of Oil of Major Canola Varieties Grown in (Golestan Province). J. Agric. Sci. Natur. Resour., Vol. 16(2).

[3] Buiatti, E.M.D,.Msc., 1997.The role of chemoprevention in cancer control. Salud Publica de Mexico, 39(4):310-317.

[4] Challem, J. J., 1997. Beta-carotene and other carotenoids: Promises Failures, and a new vision. Jornal of orthomolecular Medicine Vol.12,No.1.

[5] Chiddambara, K.N., Vanitha, A., Rajesha, j., Mahadeva Swamy, M., Sowmya, P.R., Gokare, A. Ravishankar, 2004. Invivo antioxidant activity of carotenoids from Dunaliella salina - agreen microalga, Life Science., Vol. 76, PP:13811390.

[6] Emtyazjoo, Mo., Moghadasi, Z., Rabbani, M., Emtyazjoo, Ma., Samadi, S. \& Mossaffa, N., 2012. Anticancer effect of Dunaliella salina under stress and normal conditions against skin carcinoma cell line A431 in vitro. Iranian Journal of Fisheries Sciences, 11(2); pp: 283-293.

[7] Jafari, S.M.A., Rabbani, M., Emtyazjoo, M. \& Piryaei, F., 2014. Effect of dietary Spirulina platensis on fatty acid composition of rainbow trout (Oncorhynchus mykiss) fillet. Aquacult Int, DOI 10.1007/s10499-013-9748-0.

[8] Khajehpor, M.R., 1991. Production of Industrial Vegetables. Sanati Sfahan Jahad Daneshgahi Press, 370p. (In Persian).

[9] Mohammed, M. \& Mohd, M., 2012. Production of Carotenoids (Antioxidants / Colourant) in Spirolina platensis in response to INDOLE ACETIC ACID (IAA). International Journal of Engineering Science and Technology. Vol. 3 No. 6 June 2011. 
[10] Parker, T.D., Adams, D.A., Zhou, K., Harris, M., Yu, L., 2003. Fatty acid composition and oxidative stability of cold pressed edible seed oils. J. Food Sci. 68:1240-1243.

[11] Poppel, G.V. \& Goldohm, R.A., 1995. Epidemiologic evidence for $\beta$-carotene and cancer prevention. Jour. Am J Clin Nutr, Vol.62:1393S-402S.

[12] Sadegi-aliabadi, H., Asghari, G., Mostafavi, S.A., Esmaeili, A.,2009. Solvent optimization on Taxol extraction from Taxus baccata L., using HPLC and LC-MS Daru; 17(3): 192-198.

[13] Schwartz, J. ; Shklar, G. 1988. Prevention of experimental oral cancer by extracts of spirulina-dunaliella algae. Harvard School of Dental Medicine. Pub. In Nutrition and Cancer 11, 127-134. 1988. USA.

[14] Siavash, B., Carapetian, J. \& Zare, S., 2005. Studying on lipid content and fatty acids in some varieties of colza (Brassica napus L.). Pajouhesh \& Sazandegi, No:67; pp: 95-101. (In Persian).

[15] Stryker, W.S., Stampfer, M.J., Stein, E.A., Kaplan, L., Louis, T.A., Sober, A., Wlllett, W.C., 1990. Diet, plasma levels of beta-carotene and alpha-tocopherol, and risk of malignant melanoma., Channing Laboratory, Boston, MA 02115, Am J Epidemiol; 131:597-611.- Tim et al., 2007

[16] Yang, C., Liu, H., Li, M., Yu, C., Yu, G., 2013. Treating urine by Spirulina platensis. Acta Astronautica 63, 1049-1054.

[17] Zakir Khan, Pratiksha Bhadouria and P.S. Bisen, 2005. Nutritional and Therapeutic Potential of Spirulina. Bentham Science Publishers Ltd. Current Pharmaceutical Biotechnology, No. (6): 373-379. 